\title{
Resisting Naphtha Crackers
}

A historical survey of environmental politics in Taiwan

\section{Ming-sho Ho}

\section{(2) OpenEdition \\ Journals}

Electronic version

URL: http://journals.openedition.org/chinaperspectives/6515

DOI: $10.4000 /$ chinaperspectives. 6515

ISSN: 1996-4617

\section{Publisher}

Centre d'étude français sur la Chine contemporaine

\section{Printed version}

Date of publication: 1 September 2014

Number of pages: 5-14

ISSN: 2070-3449

\section{Electronic reference}

Ming-sho Ho, « Resisting Naphtha Crackers », China Perspectives [Online], 2014/3 | 2014, Online since

01 January 2017, connection on 28 October 2019. URL : http://journals.openedition.org/ chinaperspectives/6515; DOI : 10.4000/chinaperspectives.6515

(C) All rights reserved 


\title{
Resisting Naphtha Crackers
}

\author{
A historical survey of environmental politics in Taiwan
}

MING-SHO HO

\begin{abstract}
Protests against naphtha crackers have been an important trend in Taiwan's environmentalism since their emergence in the mid-1980s. This article analyses ten protest cases (1987-2011) to understand the evolution of environmental politics. I draw the following conclusions: (1) with the growing public awareness of pollution, new petrochemical projects are increasingly facing popular opposition; (2) the environmental movement assumes less partisanship, although ideological differences between the political parties still remain; (3) the mobilising capacity of NGOs is on the rise and has become the key factor in the success of protests.
\end{abstract}

KEYWORDS: environmentalism, petrochemical industry, naphtha crackers, environmental impact assessment, Taiwan.

\section{Environmental discontent in the "petrochemical kingdom"}

$\mathrm{T}$ he petrochemical industry, which consumes energy and water while at the same time releasing massive amounts of toxic air, wastewater, and greenhouse gases, exacts a heavy environmental toll, particularly in resource-poor and densely populated Taiwan. Its expansion has given rise to widespread resistance, propelling the development of Taiwan's environmentalism. However, the existing literature in English gives scant attention to this type of environmental grievance. It was a research topic for some earlier dissertations, ${ }^{(1)}$ and there have been attempts to understand the local and religious dimension of anti-petrochemical protests. ${ }^{(2)} \mathrm{A}$ nationallevel survey of its trajectory over the past three decades is long overdue.

Comparatively, the movement against nuclear energy seems to have garnered more attention, presumably because its high political profile has repeatedly triggered intensive partisan struggles. (3) There are, however, inherent limits to understanding the contour of Taiwan's environmental politics exclusively through the lens of anti-nuclear protests. The nuclear controversy has mainly concentrated on the ill-fated fourth nuclear power plant, which was planned in the early 1980 s and is still being constructed amid increasing opposition. There has been no further expansion of nuclear energy since then. Hence the dispute, for all its intensity and visibility, has been largely contained in terms of the region and population directly affected. Taiwan's petrochemical industry, on the other hand, has undergone steady up-grading and up-scaling in capacity since the advent of the mass environmental movement. Geographically, it has also spanned different regions as petrochemical producers constantly seek new sites (see Map 1). Moreover, petrochemical development in Taiwan was often planned as a mega-project involving large-scale land reclamation and the construction of harbours and industrial complexes. While the fourth nuclear power plant was heavily criticised for its inflated budget (NT\$274 billion), it is dwarfed by petrochemical projects (the Kuokuang project of 2008 was estimated to require NT\$620 billion in investment). With this in mind, this article takes a close look at the historical evolution of popular reaction to petrochemical pollution.

In terms of its natural endowments, Taiwan is not an ideal location to develop a petrochemical industry. Not only is the island deficient in the pro- duction of natural gas and petroleum, but its high population density also aggravates the health consequences of pollution. Unforeseeable historical contingencies, however, have turned out to be a more potent force than geographical preconditions, transforming Taiwan into what economic officials like to call a "petrochemical kingdom" (shihua wangguo 石化王國).

In 1941, as the Japanese colonial government was preparing for the coming Pacific War, a petroleum refinery was built in Kaohsiung (高雄) to service the imperial fleet. The Sixth Navy Fuel Plant, then the second largest in Asia, laid the foundations for the state-owned China Petroleum Corporation's (zhongguo shiyou gongsi 中國石油公司) Kaohsiung Refinery in the postwar era. The United States advisors recommended a privately-owned plastic industry to stimulate economic growth, and American loans helped establish the Formosa Plastics Group (tai su jituan 台塑集團) when it began manufacturing polyvinyl chloride in 1954. A joint investment by American Gulf Oil and China Petroleum Corporation brought lubricant production to Taiwan in 1963.

The termination of American aid in 1965 made it necessary for Taiwan to be more economically self-reliant. There was an ambitious state-sponsored plan to produce upstream petrochemical materials for domestic consump-

The author thanks anonymous reviewers and Séverine Arsène for helpful comments, and Mei Lan Huang and Chun-hao Huang for assistance. An earlier draft was presented during a conference in the School for Oriental and African Studies, University of London. I appreciate Simona Alba Grano and Dafydd Fell's suggestions. Taiwan's National Science Council provided the grant (NSC-1032420-H-002-005-MY2) for this research.

1. Shih-jung Hsu, Environmental Protest, the Authoritarian State and Civil Society: The Case of Taiwan, PhD dissertation at University of Delaware, 1995; Hsin-yi Huang, Industrial Crises and the Emerging Environmental Movement in Taiwan: A Case Study of the Anti-Fifth Naphtha-Cracking Plant Movement, Master Thesis at Department of Social Science, State University of New York, 1993.

2. Hsin-yi Lu, "Place and Environmental Movement in Houchin, Kaohsiung," Journal of Archaeology and Anthropology, Vol. 70, 2009, pp. 47-78; Ming-sho Ho, "Protest as Community Revival: Folk Religion in a Taiwanese Anti-Pollution Movement," African and Asian Studies, Vol. 4, No. 3, 2005, pp. 237-269; Robert P. Weller, Alternative Civilities: Democracy and Culture in China and Taiwan, Boulder, CO, Westview, 1999, pp. 115-121.

3. See Dung-shen Chen, "Taiwan Antinuclear Movement in the Wake of the Fukushima Disaster, Viewed from an STS Perspective, " East Asian Science, Technology and Society, Vol. 5, No. 4, 2011, pp. 568-569; Mei-fang Fan, "Environmental Justice and Nuclear Waste Conflicts in Taiwan," Environmental Politics, Vol. 15, No. 3, 2006, pp. 417-434; Ming-sho Ho, "The Politics of Anti-Nuclear Protest in Taiwan: A Case of Party-Dependent Movement (1980-2000)," Modern Asian Studies, Vol. 37, No. 3, 2003, pp. 683-708, "The Fukushima Effect: Explaining the Recent Resurgence of the Anti-nuclear Movement in Taiwan," Environmental Politics, forthcoming; Michael Hsin-huang Hsiao et al.," "The Making of Anti-nuclear Movements in East Asia: State-Movements Relationships and Policy Outcomes," in Yok-Shiu Lee and Alvin So, Asia's Environmental Movements, New York, M. E. Sharpe, 1998, pp. 252-268. 
tion. China Petroleum Corporation built its naphtha cracker No. 1 (yi ging —輕) (4) in 1968. During the "Ten Major Development Projects" (shi da jianshe 十大建設) of the 1970s, the petrochemical industry was seen as a lynchpin critical to the nation's industrial upgrading. China Petroleum Corporation's naphtha crackers No. 2 to 4 were subsequently built from 1975 to 1984

In hindsight, Taiwan is a successful case of "backward integration" in that the downstream textile and plastic industries, then the mid-stream chemical fibre and chemical industries, and finally the upstream petrochemical industry were sequentially established to form a well-linked and internationally competitive sector. ${ }^{(5)} \mathrm{A}$ nation's petrochemical capacity is usually measured by the volume of ethylene production, one of the main products of naphtha cracking. By that index, Taiwan ranked number nine globally in 2010. ${ }^{(6)}$ It is therefore no wonder that Taiwan's petrochemical producers proudly proclaim themselves "leading actors" in the creation of the "economic miracle." (7)

However, this overtly triumphant remark fails to take the environmental cost into account. Prior to the mid-1980s, all of these petrochemical projects were launched with little popular opposition, as most people were either unaware of pollution or afraid of voicing their dissent due to political repression. As stressed by commentators, the year 1987 constituted a "watershed" in Taiwan's environmental protection, ${ }^{(8)}$ when the landscape for the petrochemical industry was radically altered. In the past, petrochemical producers used to claim that their investments were heartily welcomed by host communities with dragon dance (wulong 舞龍) and lion dance (wushi 舞獅) performances; now, they are more likely to be avoided like a plague. Following are the major socio-political changes since 1987:

First, the termination of martial-law rule in 1987 released pent-up grievance against environmental degradation that sustained a strong wave of anti-pollution activism. Local pollution victims organised NIMBY-style selfhelp protests to demand immediate improvements or monetary compensation. Middle-class professionals set up environmental NGOs, which offered assistance to local protestors and advocated policy changes on a national scale. ${ }^{(9)}$ The first protest movement to oppose a new naphtha cracker occurred in July 1987, two weeks after the government announced the lifting of martial law. In addition, the Taiwan Environmental Protection Union (taiwan huanjing baohu lianmeng 台灣環境保護聯盟), which used to be Taiwan's most influential environmental NGO, was founded in November of the same year. Together they constituted a broadly-based popular front to resist further expansion of the petrochemical industry.

Secondly, in tandem with political liberalisation, Taiwan's opposition coalesced into the Democratic Progressive Party (DPP) in 1986, in its challenge to the authoritarian rule of the Kuomintang (KMT). The opposition party initially represented the native population, who chafed under the minority rule of Mainlanders. However, as the KMT successfully built its broad social basis, the political opposition had to organise itself as a catchall party, recruiting "anti-KMT members from all social sectors." (10) The rise of social movements coincided with the DPP's founding, which encouraged the latter to ally with the protestors to form a united front against the KMT government and gave the nascent opposition party a hue of leftwing progressive politics. Witnessing the widespread rise of environmental grievances, DPP activists joined anti-pollution protests, and their politicians championed the need to put environmental protection ahead of economic development. The involvement of a major opposition party politicised Taiwan's nascent environmentalism by giving it a vital role in party competition. ${ }^{(11)}$ Before its assumption of national power in 2000, the DPP consistently presented a more pro-environmental profile than its KMT rival. However, during its incumbency from 2000 to 2008, the DPP shifted towards a more pro-business stance by shelving its erstwhile environmental commitments, thus severing its previous political alliance with environmentalists. There are signs that the DPP has adopted a more pro-environmental posture since losing national power in 2008. ${ }^{(12)}$ As the following analysis will show, its attempt to rebuild a coalition with environmentalists remains fraught with difficulties. Finally, Taiwan's Environmental Protection Administration was also formed in August 1987, as the KMT government acknowledged the need to address popular demand for better environmental quality. From the very beginning, environmental officials adopted a technocratic approach to environmental problems in the belief that disputes can be solved in a professional and politically neutral manner. Upgrading administrative capacity and legislating regulations were thought of as top priorities. Environmental impact assessments, as codified in 1994, exemplified the rationalistic outlook of environmental officials, because the scientific evaluation of development projects by qualified experts was considered the best and most enlightened guideline for policymakers. ${ }^{(13)}$ However, the unintended consequence was that opponents to petrochemical expansion used the review sessions to publicise their scepticism, while officials and business representatives tried to downplay the estimated harmful consequences, all of which severely damaged the public credibility of environmental impact assessments. ${ }^{(14)}$

In short, with the emergence of the environmental movement, political opposition, and environmental regulation, Taiwan's petrochemical industry entered a rocky terrain even though it still enjoyed state sponsorship under both the KMT and DPP governments.

This article will analyse ten cases of naphtha cracker investments from 1987 to 2011 to understand the contours of environmental politics over the past three decades. This inquiry is guided by the following questions: What factors determine the outcome of anti-petrochemical protests? What roles do stakeholders such as local residents, local governments, and NGOs

4. Because of the statist origin, Taiwan officials and businesses number the naphtha crackers consecutively and use these shortened epithets in lieu of the official project titles. For example, the FPG's naphtha cracker No. 6 stands for "the Yunlin Offshore Basic Industry Park." This article follows this practice for the sake of brevity.

5. Wan-wen Chu, "Changye zhengce de shifan: Taiwan shihuaye de chengzhang" (The demonstration of effect of industrial policy: The birth of Taiwan's petrochemical industry), Taiwan shehui yanjiu qikan (Taiwan: A Radical Quarterly in Social Studies), Vol. 27, 1997, pp. 97-138.

6. Petrochemical Industry Association of Taiwan (ed), Shihua nianbao (Annual report of petrochemicals), Taipei, Petrochemical Industry Association of Taiwan, p. 50.

7. China Petroleum Corporation (ed), Shiyou gongye: Taiwan jingji qiji de zhujiao (The petrochemical industry: The leading actor in Taiwan's economic miracle), Taipei, Kaopao, 1992.

8. Jack F.Williams and Ch'ang-yi David Chang, Taiwan's Environmental Struggle: Toward a Green Silicon Island, London: Routledge, 2008, p.166.

9. Michael Hsin-huang Hsiao, "Environmental Movements in Taiwan," in Yok-Shiu Lee and Alvin So, Asia's Environmental Movements, New York, M. E. Sharpe, 1999, pp. 31-54; Tadayoshi Terao, "An Institutional Analysis of Environmental Pollution Disputes in Taiwan: Cases of 'Self-relief'," Developing Economies, Vol. 40, No. 3, 2002, pp. 284-304.

10. Shelley Rigger, Taiwan Democratic Progressive Party, Boulder, CO, Lynne Riener, 2001, p. 11.

11. Ming-sho Ho, "The Politics of Anti-Nuclear Protest in Taiwan: A Case of Party-Dependent Movement (1980-2000)," Modern Asian Studies, Vol. 37, No. 3, 2003, pp. 683-708; Sunhyuk Kim, "Democratization and Environmentalism: South Korea and Taiwan in Comparative Perspective," Journal of African and Asian Studies, Vol. 35, 2000, pp. 287-302.

12. Ming-sho Ho, "Understanding the Trajectory of Social Movements in Taiwan (1980-2010)," Journal of Contemporary Chinese Affairs, Vol. 39, No. 3, 2010, pp. 16-18.

13. Shui-yan Tang and Ching-ping Tang, "Democratizing Bureaucracy: The Political Economy of Environmental Impact Assessment and Air Pollution Fees in Taiwan," Comparative Politics, Vol. 33, No. 1, 2000, pp. 81-99

14. Ming-sho Ho, "Contested Governance between Politics and Professionalism in Taiwan," Journal of Contemporary Asia, Vol. 34, No. 2, 2004, pp. 238-253. 
play in these disputes? Over the years, which actors have been gaining influence in environmental decision-making? Since the petrochemical industry contributed a significant share of pollution, an analysis of its challengers helps us understand the trajectory of Taiwan's environmentalism. The research data are primarily based on existing research literature and journalistic reports.

\section{Anti-naphtha cracker movements in Taiwan}

Taiwan's first four naphtha crackers were state-owned and were built without visible opposition. As noted above, things took an abrupt turn in 1987, with all six subsequent naphtha-cracking projects arousing resistance in varying degrees. They are (A) China Petroleum Corporation's naphtha cracker No. 5, (B) Formosa Plastics Group's naphtha cracker No. 6, (C) Tuntex's naphtha cracker No. 7, (D) China Petroleum Corporation's naphtha cracker No. 8, (E) China Petroleum Corporation's upgrading of naphtha cracker No. 3, and (F) the Kuokuang petrochemical project. Since three of them $(B, D$, and $F$ ) shifted the sites selected for construction, the six projects comprise a total of ten cases. Among them, only three projects ( $A, B$, and E) finally went into operation, while the rest were eventually abandoned.

As hinted above, Taiwan's environmentalism was born in the crucible of political transition. The following analysis will look at the unfolding of anti-naphtha cracker protests in three periods, 1987-1999, 2000-2007, and 2008-2011.

\section{From liberalisation to power shift, 1987-1999}

The 1987 lifting of martial law set forth a political liberalisation that allowed environmental grievances to be expressed in street protests. In this period, the political opposition and the environmental movement grew in tandem. In 1987, China Petroleum Corporation's naphtha cracker No. 5 and FP's naphtha cracker No. 6 were the first two projects that incurred popular resistance, followed by Tuntex's naphtha cracker No. 7 in 1994 and China Petroleum Corporation's naphtha cracker No. 8 in 1999.

China Petroleum Corporation's naphtha cracker No. 5 was planned to replace its No. 2, which went into operation in 1975; both were located in Houchin (後勁), a former agricultural village situated on the edge of Kaohsiung City. However, the Japanese wartime decision to build a navy fuel plant by requisitioning farmland and the post-war industrial expansion permanently changed the villagers' fate. For more than 40 years, Houchin residents suffered from toxic air and polluted groundwater, and their health and crops were severely damaged. Taking heed of the relaxed political at- mosphere, their rebellion erupted in July 1987, and unexpectedly, their barricading of one of the complex gates, a symbolic gesture of their rejection of the new naphtha cracker, lasted for more than three years. ${ }^{(15)}$

The Houchin movement was one of the best-known environmental protests in the post-martial law era, and its violence, including several rounds of brutal confrontations with the police, revealed the magnitude of long-silenced discontent. DPP politicians supported the protest, as its emergence was widely perceived to be an indication of the KMT government's failure to protect the common people. In fact, one of the Houchin protest leaders joined the DPP and won the legislative election in 1989.

In May 1990, there was a referendum in Houchin, in which $61 \%$ of those who voted indicated their "determined opposition" while 39\% were in favour of "negotiation with China Petroleum Corporation." Facing this entrenched opposition, the KMT government adopted a two-pronged strategy. On the one hand, a fund of NT\$1.5 billion was offered, and the interest gained was used for a variety of good-neighbour compensations such as

15. Hsin-yi Lu, "Place and Environmental Movement in Houchin, Kaohsiung," Journal of Archaeology and Anthropology, Vol. 70, 2009, pp. 47-78; Ming-sho Ho, Protest as Community Revival: Folk Religion in a Taiwanese Anti-Pollution Movement," African and Asian Studies, Vol. 4, No. 3, 2005, pp. 237-269. 
subsidised cooking gas and free school lunches. An official promise was made to relocate the new naphtha cracker in 25 years. On the other hand, the government mobilised police and security agents on a massive scale to monitor protest leaders and suppress their activities. China Petroleum Corporation subsequently began building the project in September 1990, and it went into operation in 1994.

Formosa Plastics Group had long intended to operate its own naphthacracking facility so as to end its dependence on the state-owned source. Economic liberalisation in the mid-1980s finally convinced economic bureaucrats to abandon the state monopoly on upstream production. However, Formosa Plastics Group's ambition to build an integrated petrochemical empire was thwarted by the rise of environmental protests that obliged it to shift its projected site from Wuchieh (五結) Township, Yilan County (B1), to Kuanyin (觀音) Township, Taoyuan County (B2), and eventually to Mailiao (麥寮) Township, Yunlin County (B3).

Yilan was Formosa Plastics Group's preferred site, as the location was close to a harbour facility. Local opposition was initiated in early 1987 by DPP activists who later established the Taiwan Environmental Protection Union's Yilan branch. They closely collaborated with a nonpartisan county magistrate, Chen Ting-nan (陳定南) (1981-1989), who built up an incorruptible and pro-environment reputation during his tenure. Chen had worked for Formosa Plastics Group before launching his political career, and his eloquent and persuasive performance in a televised debate with the Formosa Plastics Group president in December 1987 boosted the morale of the Yilan environmentalists by gaining national support. As a result, the bruised Formosa Plastics Group turned its attention to Taoyuan, halting its Yilan plan.

In Yilan, local KMT politicians largely supported petrochemical investment, so the dispute evolved into a partisan rivalry. In 1990, as Formosa Plastics Group obtained the endorsement of the KMT central government, a second offensive to build its naphtha cracker project in Yilan began. By then, Chen Ting-nan had joined the DPP and been elected to the legislature. Chen again led the protest movement, including a large-scale demonstration in Taipei in December 1990. Moreover, Chen was succeeded by another DPP county magistrate who was equally opposed to the petrochemical project. Thus, the KMT central government was unable to repeat the same carrot-andstick strategy that it used to deal with the Houchin protest. In 1991, Formosa Plastics Group finally abandoned its dream of establishing a petrochemical production centre in Yilan.

Yilan has been hailed as the "holy land of Taiwan's democracy" because non-KMT executives governed the county continuously from 1981 to 2004. The victory over the powerful petrochemical conglomerate helped consolidate the DPP's pro-environment credentials. After Chen, the DPP's county magistrates successfully promoted local culture and tourism, which were presented as much more attractive alternatives to heavy industrialisation. The "Yilan experience" became a political asset as the DPP sought to contest the KMT for national power. ${ }^{(16)}$

By contrast, the Taoyuan location was persistently Formosa Plastics Group's number two choice. The company began to take interest in this alternative only after its Yilan proposal became mired in local opposition. Starting in late 1987, Kuanyin residents established their self-help organisation to coordinate protest activities, and they were joined by local DPP politicians and activists. Meanwhile, KMT leaders were generally supportive of petrochemical investment. Compared to Yilan, the opposition party's strength in Taoyuan was not as well established, and that was one of the reasons why the Kuanyin movement appeared weaker. Nevertheless, DPP politicians benefited from their sponsorship of local environmental protest. In 1989, there were three major elections for county magistrate, provincial assemblymen, and legislator. The DPP candidates garnered $53.7 \%$ of the vote in Kuanyin Township, compared with the county average of $35.0 \%$. (17) Subsequently, Kuanyin became an atypical DPP stronghold in the generally pro-KMT Taoyuan County.

The KMT central government did its best to facilitate the Formosa Plastics Group's investment in Taoyuan. The government granted a permit in July 1988, and the Ministry of Economic Affairs' officials even tried to persuade local opponents. Formosa Plastics Group ultimately decided to give up Taoyuan for Yilan in 1990 because of higher land costs and the absence of harbour facilities.

After the second setback in Yilan, Formosa Plastics Group followed the official recommendation to consider Mailiao Township, Yunlin County, in March 1991. Yunlin is located in Taiwan's south-western agricultural heartland, and as farming income had been artificially repressed by the government to speed up industrialisation, it remained one of Taiwan's most impoverished counties. Mailiao was an underdeveloped coastal township with a high population outflow, making it easier for the pro-development camp to frame the petrochemical industry as an opportunity for local prosperity. The Taiwan Environmental Protection Union's Yunlin branch was set up to oppose Formosa Plastics Group in an attempt to replicate the Yilan experience, and most of its participants were DPP activists; however, the DPP was much weaker, and the KMT county magistrate even managed to mobilise a large-scale pro- Formosa Plastics Group rally in July 1991. In the end, local environmentalists failed to garner sufficient support and were unable to forestall the petrochemical project.

At that time, Taiwan's economic officials were eager to lure Formosa Plastics Group to Mailiao for fear that the latter might divert its investment to China. Consequently, naphtha cracker No. 6 was given a number of benefits previously denied to private business. Formosa Plastics Group was allowed to reclaim tidal land for its site and to own an industrial harbour, and the government even built a huge water supply project primarily for its use. Since naphtha cracker No. 6 went into operation in 1999, the government has given the green light to its expansion several times. As a result, Formosa Plastics Group's Mailiao project grew to become the world's biggest industrial park specialising in petrochemicals, accounting for $75 \%$ of Taiwan's ethylene production and $18 \%$ of its carbon dioxide emission. ${ }^{18)}$

Although the Formosa Plastics Group's naphtha-cracking project did not proceed smoothly in the beginning, there was a demonstration effect in that the government was willing to sponsor a private venture in the upstream petrochemical industry with privileges and subsidies. Tuntex (dongdishi 東帝 \pm ), a textile and chemical fibre company that enjoyed good relations with the KMT, joined hands with the Yieh Loong (燁隆) Group, a steel company, to propose the Pinnan Industrial Zone (bin nan gongye qu 濱南工業區) project in 1994, in which Tuntex planned to build naphtha cracker No. 7.

The Pinnan project was located in Chiku (七 股) Township, Tainan County, ${ }^{(19)}$ where a tidal lagoon nurtured oyster production and sheltered

16. For a chronicle of the Yilan movement, see Environmental Protection Bureau of Yilan County, Yilanxian huanjing baohu nianjian (Yearbook of Environmental Protection in Yilan County), Yilan, Yilan County Government, 1994, pp. 34-36.

17. The author's calculation of electoral data from the archives of the Central Election Commission.

18. Ching-hsuan Huang, "Shihuaye: yao liuxia ta, jiuyao guanhao ta" (Petrochemical industry: If you want to keep it, you need to manage it well), Tianxia, Vol. 453, 2010, p. 96.

19. Following reform of the local administration in 2011, Tainan County was merged into Tainan City, and the same happened with Kaohsiung County/ City. However, I will use the former system for the sake of greater precision. 
the endangered blackface spoonbills in their migratory route. This megaproject's plan to spend NT\$470 billion to reclaim 3,500 hectares of land from the lagoon immediately aroused the joint opposition of local fishermen and oystermen as well as bird lovers. ${ }^{(20)}$ Anti-dam activists in the inland area of southern Taiwan also joined this campaign because the government was attempting to develop new water sources. (21) Soon the movement leadership fell to Su Huan-chih (蘇煥智), then an opposition legislator, who led a long march throughout 22 townships in Tainan County over eight days to mobilise the opposition in 1996. Learning from the lesson in Yilan, Tuntex beefed up its public relation activities to build its local support base. Not only were KMT politicians recruited into the pro-development camp as expected, but also DPP county magistrate Chen Tang-shan (陳唐山) (19942001) came out in favour of this project. In 1997, as Chen was seeking his re-election in the DPP primary, Su stood as a challenger and promised to drop his bid as long as Chen publicly opposed the Pinnan Industrial Zone. Thus, this controversy evolved into an internecine power struggle within the DPP, and even its national leadership was unable to reconcile the local conflict. Environmentalists complained about the decline of the DPP's commitment to environmental protection, claiming that "the DPP caused harm to the movement against the anti-naphtha cracker No. 7" because many people were asking "why the DPP opposed the naphtha cracker No. 5 and No. 6, but not No. 7." (22)

Luckily for opponents, environmental impact assessments were written into law at the same time as the Pinnan project was proposed. It therefore became the first major case to be reviewed under this new regulation. The 1994 law granted veto power to environmental officials in that major construction projects cannot proceed without clearing the environmental impact assessment process in the first place. Utilising this strategic space, the Pinnan opponents raised a number of concerns, such as the ecological damage caused by lagoon reclamation, the economic impact on local aquaculture, and the deficient water supply. Facing these questions, the developers had to spend time collecting research data to convince the official reviewers. In the end, the government finally approved the Pinnan project in December 1999, just three months before the presidential election in which the KMT lost national power. Although the timing was highly suspicious, opponents did succeed in delaying this project as long as possible. By way of comparison, Formosa Plastics Group spent four months and nine months respectively in obtaining government permission for its Yilan and Taoyuan plans, but the Tuntex Group was entangled in the environmental impact assessment process for more than four years.

Things took an unexpected turn after the DPP became the ruling party in 2000. Firstly, Tuntex and the Yieh Loong Group were the type of businesses that were able to expand swiftly because their political connections with the KMT allowed them easy access to bank loans; they therefore suffered financial setbacks when their political backers fell out of power. The Yieh Loong Group was sold to state-owned China Steel in 2000, while Tuntex was forced to declare insolvency the following year. Secondly, Su Huan-chih was elected Tainan county magistrate in 2001, which made it practically impossible to resuscitate the Pinnan project. In 2009, the Chiku lagoon was designated part of Taijiang National Park (台江國家公園) and became famous for its eco-tourism.

In hindsight, China Petroleum Corporation appeared to win a pyrrhic victory at its naphtha cracker No. 5 because it had made a 25-year relocation promise. Although the exact meaning of the official pledge was subject to different interpretation, Houchin residents maintained the maximalist view that the entire Kaohsiung Refinery, not just the ill-fated naphtha cracker, should be gone by the end of 2015. In addition, China Petroleum Corporation's rival Formosa Plastics Group had rapidly expanded its petrochemical capacity since its naphtha cracker No. 6 was a greenfield project upon the newly reclaimed land. Thus, soon after its naphtha cracker No. 5 went into operation, China Petroleum Corporation began planning its replacement, naphtha cracker No. 8, as well as other oil-refining facilities and private midstream producers in Tashe (大社) and Jenwu (仁武) that relied on China Petroleum Corporation's supply. Two sites, Fangliao (枋寮) Township, Pingtung County (D1), and Putai (布袋) Township, Chiayi County (D2), were successively proposed, but both ended in failure.

In March 1999, China Petroleum Corporation formally unveiled a plan to build naphtha cracker No. 8 in Pingtung, on farmland owned by the stateowned Taiwan Sugar Corporation. Upon hearing the news, the DPP County Magistrate Su Chia-chuan (蘇嘉全) (1998-2005) immediately expressed his disagreement, and his position was echoed by other DPP politicians. Although Pingtung was predominantly agricultural, it suffered from air pollution emitted from the heavy industries in the greater Kaohsiung metropolitan area. In addition, the mid-1990s witnessed a surge in local conservation movements that helped raise environmental consciousness. Some of the activists entered the local government during Su's tenure, and thus facilitated the coordination between the DPP and environmentalists. At that time, Su attempted to imitate the Yilan model by promoting tourism so that high-pollution industries were not welcome. Since high-pollution industries were unpopular in Pingtung, even the traditionally pro-development KMT politicians had to act cautiously. In the 2001 magistrate election, the KMT candidate criticised Su's outright rejection of China Petroleum Corporation's naphtha cracker No. 8, yet he refrained from endorsing the project explicitly.

In the latter half of 1999, China Petroleum Corporation diverted its attention to Chiayi for a brief period (see below), and made its second attempt in Pingtung in 2002. As with the Formosa Plastics Group's preference for Yilan, China Petroleum Corporation considered Pingtung the best available option. Su Chia-chuan remained adamant in his refusal, thus frustrating the plan to build a new naphtha cracker. The Pingtung case was therefore unique in that principled opposition from a local executive successfully prevented petrochemical industrialisation despite little mobilisation of civil society.

The Chiayi episode of China Petroleum Corporation's naphtha cracker No. 8 emerged largely as an effort to boost the KMT's electoral campaign for the 2000 presidential election, in which the ruling party faced a real chance of losing power. ${ }^{(23)}$ The then KMT vice-presidential candidate Vincent Siew (蕭萬長) hailed from Chiayi, and since he had once led the Ministry of Economic Affairs, which supervised the state-owned companies, his subordinate officials decided to bring naphtha cracker No. 8 to Chiayi so that Siew could claim to have brought development to his hometown.

20. The source on the Chiku dispute comes from Han-shen Pan, Shidi kongjian de shehuixing shengchan: yi Tainan Jigu shidi wei guan (The Social Production of Wetland Space: A Case Study of Chiku Wetland in Taiwan), MA dissertation at National Taiwan University, 1996.

21. Anru Lee, "Southern Green Revolution: Urban Environmental Activism in Kaohsiung, Taiwan," City and Society, Vol. 19, No. 1, 2007, pp. 114-138. Takao Green Association (ed), Nan Taiwan lüse geming (Green Revolution in Southern Taiwan), Taipei, Chenxing, 1996.

22. Huan-chih Su and Chih-cheng Hsieh, Heimian pilu de xiangchou (The Nostalgia of Blackface Spoonbill), Taipei, Shibao, 1997, p.162.

23. The information on the Chiayi movement against naphtha cracker No. 8 comes from Chi-Jung Lu, Difang paixi, shehui yundong yu huangjing zhili: yi Baqing zai Yun-Jia shechang juece fenxi weili (Local Faction, Social Movement and Environmental Governance: Taking the 8th Naphtha Cracking Project for Example), MA dissertation at National Chengchi University, 2007. 
In August 1999, seven months before the presidential election, China Petroleum Corporation abruptly announced plans to build naphtha cracker No. 8 on the government's abandoned salt fields. The Putai plan won the immediate support of local KMT politicians, who controlled the local government. To welcome the project, Chiayi County government even broke its previous agreement with a private developer and mobilised a mass rally for "the construction ceremony." Like Chiku, Putai was an aquaculture and fishing centre whose main economic activities were easily threatened by the encroachment of the petrochemical industry. A local opposition movement emerged and received assistance from other environmental NGOs in southern Taiwan; however, the opposition appeared weaker, as the pro-development KMT politicians dominated local public opinion.

Even though the Putai plan was apparently part of the KMT's campaign tactics, the DPP camp did opt to choose the opposite stand. Some Putai activists approached Chen Shui-bian, then the DPP presidential candidate, but Chen declined to take a clear stand - obviously a strategic consideration to accommodate the predominantly pro-development sentiment in Chiayi. Nevertheless, the KMT's setback in the 2000 presidential election sealed the fate of the Putai plan. Once the DPP assumed power, China Petroleum Corporation frankly acknowledged that the Putai site was not economically feasible and turned its attention back to Pingtung. In 2001, the local executive position fell to the green camp as Chen Ming-wen (陳明文) became county magistrate from 2002 to 2009. Following the example of Yilan and Pingtung, Chen sought to promote smokestack-free development as an alternative. Even though China Petroleum Corporation never seriously considered Putai as its construction site, local KMT politicians blamed the DPP for losing the opportunity for industrialisation. Hence, as the 2004 county magistrate election approached, the KMT camp even mobilised a campaign to "bring back naphtha cracker No. 8."

\section{The DPP era, 2000-2007}

The year 2000 witnessed Taiwan's first regime change as the DPP won the presidential election. The DPP had used to play the role of political ally to the environmental movement. However, once it obtained national power, its stance gravitated toward a more pro-development pole. In 2005, the DPP government promoted China Petroleum Corporation's upgrading of naphtha cracker No. 3 as well as the Kuokuang petrochemical project.

The inability to establish a new production site forced China Petroleum Corporation to consider other alternatives, such as expanding its existing plant in Linyuan (林園) Township, Kaohsiung County, an idea first raised in 2004. Prior to the rise of the Formosa Plastics Group's naphtha cracker No. 6, Linyuan Industrial Park was Taiwan's most important petrochemical centre, and naphtha crackers No. 3 and No. 4 were located there. Due to its earlier development, Linyuan was notorious for pollution. In 1988, a pollution incident gave rise to a mass protest in which victims barricaded the industrial park for three weeks, practically shutting down Taiwan's petrochemical supply (the so-called Linyuan Incident). (24) Since Linyuan and Houchin were both communities with a protracted history of environmental suffering and anti-pollution resistance, expansion projects were certain to meet local hostility.

China Petroleum Corporation's original plan was to requisition 55 hectares of private land for a new naphtha cracker at a total investment of NT\$42.6 billion. In March 2005, the Linyuan township mayor led a protest against this project, thereby initiating the local opposition movement. In the be-

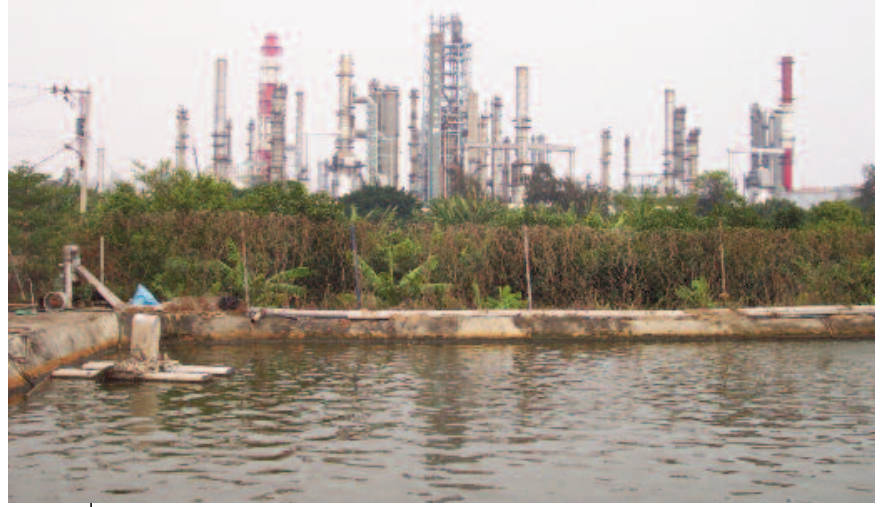

Photo 1 - China Petroleum Corporation's Naphtha Cracker No. 3 in Linyuan Township. Taiwan's petrochemical facilities are often located in the vicinity of agricultural area. The picture shows a fishpond just outside the perimeter of the industrial complex. ๑ Ming-sho Ho

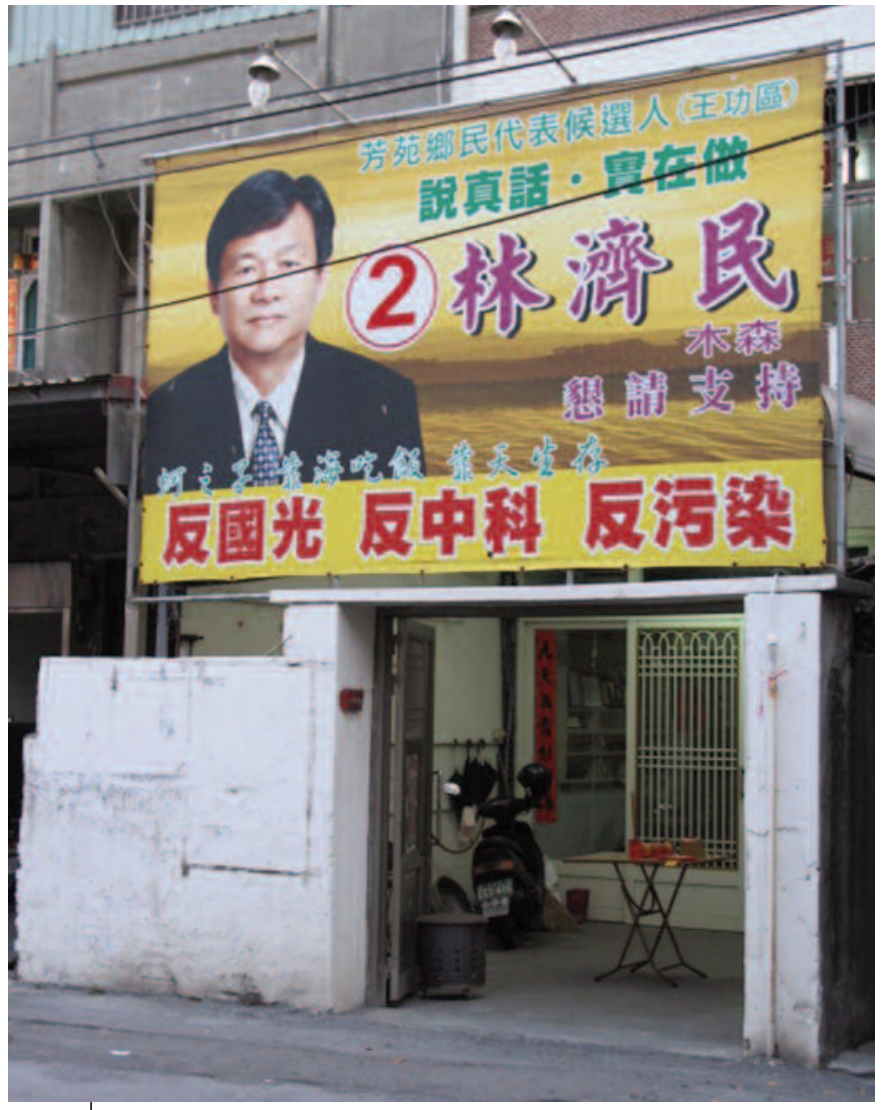

Photo 2 - An anti-Kuokuang politician in Fangyuan Township. The anti-Kuokuang movement succeeded partly because of the strong local opposition to the project. This candidate for a township-level election featured his anti-pollution commitment during the campaign. $\odot$ Ming-sho Ho

ginning, local politicians of all stripes led the movement, but their involvement subsequently declined for two reasons. First, China Petroleum Corporation decided to scale down the project by "upgrading" the existing

24. Ming-sho Ho and Feng-san Su, "Control by Containment: Politics of Institutionalizing Pollution Disputes in Taiwan," Environment and Planning A, Vol. 40, No. 10, 2008, p. 2409. 
naphtha cracker No. 3 rather than "expanding" it, and abandoned the attempt to enlarge its factory complex. Secondly, China Petroleum Corporation promised to offer more monetary compensations to the local community. Consequently, by the time the project entered the official review in 2007, politicians had shifted towards a more conciliatory stand, emphasising the need for "hometown prosperity." Determined activists sought the help of professional NCOs but found it increasingly difficult to mobilise local participants after the defection of the political leadership. With the conclusion of the environmental impact assessment review in December 2008, the opposition movement collapsed.

The Linyuan movement was conspicuously lacking in partisanship, quite unlike the usual pattern of DPP involvement in anti-pollution activism. One of the reasons was that the DPP's Kaohsiung county magistrate, Yang Chiuhsing (楊秋興) (2002-2010), was in favour of the petrochemical investment, which he eagerly solicited to demonstrate his economic performance. Reflecting the pro-business turn of the DPP central government, Yang had once been an environmental activist, having co-founded the Taiwan Environmental Protection Union's Kaohsiung branch in 1988 before standing for election for the first time in 1991. During the Linyuan Incident of 1988, Yang even led the Taiwan Environmental Protection Union members to join the victims' barricade. Yang's metamorphosis from an environmental warrior to a pro-development politician was generally in sync with the ideological drift of the DPP during its incumbency. (25)

A scaled-down upgrading project was not enough to maintain petrochemical production after the relocation deadline in 2015 . Hence, with the DPP government's endorsement, China Petroleum Corporation launched a joint investment with private business to form the Kuokuang Petrochemical (guoguang shihua 國光石化) Company in January 2006, which first planned a new naphtha cracker in Taihsi (台西) Township, Yunlin County (F1), and then in Tacheng (大城) Township, Changhua County (F2). (26)

China Petroleum Corporation turned its attention to Yunlin in 2005, when the Kyoto Protocol became effective. Since then, Taiwan's environmental NGOs had launched several protests against the DPP government's support for petrochemical expansion without regard for its impact upon climate change. The first Kuokuang project was a massive investment of NT\$401 billion to reclaim 1,800 hectares of the Taihsi seashore. Like its northern neighbour, Mailiao, Taihsi was an impoverished and backward village. With the mobilisation of the local KMT politicians, the Township Office was able to carry out an opinion poll that showed $54 \%$ of the residents supporting Kuokuang. Environmentalists were weakly organised in Yunlin, just as 15 years before, when Formosa Plastics Group decided to establish its naphtha cracker No. 6 in Mailiao. The Taiwan Environmental Protection Union's Yunlin branch had long been moribund until its reorganisation in 2006, but even revitalised it had only five active members who took part in the antiKuokuang protest.

It looked as if the Kuokuang project was sure to be realised, given the enfeebled state of the local opposition. However unanticipated developments forestalled the plan. First, the DPP's Su Chih-fen (蘇治芬) won the county magistrate election in 2005 , and she upheld an agriculture-first policy that sought to restrain the growth of heavy industries. In particular, with the colossal naphtha cracker No. 6 in mind, Su attempted to institutionalise polluter compensation and to impose a county-specific carbon tax on industrial producers. Although both proposals failed to pass the KMT-controlled county council, the Kuokuang management sensed the negative change in the political wind. Secondly, the Taihsi project was mired in the environmental impact assessment process. In March 2008, the Environmental Protection Administration determined that the case should proceed to the second stage of review, which prompted Kuokuang to decamp to Changhua County.

\section{The return of the KMT, 2008-2011}

The conservative KMT's return to power coincided with the shift of the Kuokuang site to Changhua. It was widely thought that the KMT's pro-business and pro-development ideology should have facilitated this mega-project. In Tacheng, the Kuokuang project initially received bipartisan support when it was formally announced in June 2008, and its township office consequently produced an opinion poll showing $98 \%$ in favour as if to outbid Taihsi. KMT Changhua County Magistrate Cho Po-yuan (卓伯源) (2005-present) saw Kuokuang as a credit to himself and vowed to facilitate its construction. Additionally, the new KMT government led by Ma Ying-jeou since May 2008 also supported this project, even though it was first proposed during the DPP era. The new Kuokuang project grew to an estimated investment of NT\$620 billion and 2,900 hectares reclaimed from Tacheng wetland.

The second Kuokuang project nevertheless faced greater opposition. Changhua environmentalists were better organised; for example, the Taiwan Environmental Protection Union's local branch had continued to play an important role since its founding in 1988, unlike its counterpart in Yunlin. Although few Tacheng residents joined the opposition, its northern neighbour, Fangyuan (芳苑) Township, was a famous oyster production site with previous environmental protest experience, and thus provided rank-and-file protestors. Moreover, Changhua activists were able to secure assistance from national NCOs such as the Society of Wilderness (huangye baohu xiehui 荒野保護協會), Taiwan Rural Front (taiwan nongcun zhenxian 台灣農 村陣線), Taiwan Environmental Information Centre (huanjing zixun xiehui 環境資訊協會), and Youth Synergy Foundation (qing pingtai jijin hui 青平台 基金會), thus successfully placing this local environmental dispute under the national spotlight.

By the summer of 2010, Taiwan's mainstream media had begun publishing reportage more sympathetic to the anti-Kuokuang movement. Literary writers (especially under the leadership of native poet Wu Sheng [吳晟]), college professors, and medical doctors launched signature campaigns to defend the precious wetland ecology. Similar to the role of the blackface spoonbill in the case of naphtha cracker No. 7, anti-Kuokuang activists highlighted the endangered Indo-Pacific humpbacked dolphins (bai haitun 白海豚), whose habitat was about to be destroyed by the massive reclamation engineering works. The universally beloved dolphins became oft-used figures throughout the anti-Kuokuang mobilisation. Following the rise of public scepticism, Weng Chin-chu (翁金珠), the former DPP county magistrate (2002-2005), joined the opposition camp in September 2010. Weng's conversion was noteworthy in that she attempted to develop the Tacheng wetland and invited heavy industries there during her tenure, souring her relations with local Taiwan Environmental Protection Union activists. Like Yang Chiu-hsing in Kaohsiung County, Weng played an important role in or-

25. Information on the Linyuan protest against the upgrading of naphtha cracker No. 3 comes from Ming-sho Ho, "Co-opting Social Ties: How the Taiwanese Petrochemical Industry Neutralized Environmental Opposition," Mobilization: An International Journal, Vol. 15, No. 4, 2010, pp. 447-463.

26. The data for the anti-Koukuang movement is primarily based on Chih-cheng Hsieh and Ming-sho Ho, Baqing you Taiwan: Guoguang shihua de gushi (The Naphtha Cracker That Travels around Taiwan: The Story of the Koukuang Petrochemical Project), Taipei, Rive Gauche (Zuoyan), 2011. 
Table 1 - Protests against naphtha-cracking projects in Taiwan (1987-2011)

\begin{tabular}{|c|c|c|c|c|c|}
\hline Project & Period & Location & $\begin{array}{l}\text { Civil-society } \\
\text { mobilisation }\end{array}$ & $\begin{array}{l}\text { The DPP's } \\
\text { attitude }\end{array}$ & $\begin{array}{l}\text { Protest } \\
\text { outcome }\end{array}$ \\
\hline $\begin{array}{l}\text { (A) China Petroleum Corporation's } \\
\text { naphtha cracker No. } 5\end{array}$ & 1987-1990 & $\begin{array}{l}\text { Houchin, } \\
\text { Kaohsiung City }\end{array}$ & Strong & Oppositional & Failure \\
\hline \multirow{3}{*}{$\begin{array}{l}\text { (B) Formosa Plastics Group's naphtha } \\
\text { cracker No. } 6\end{array}$} & \multirow{3}{*}{ 1987-1991 } & $\begin{array}{l}\text { Wuchieh, } \\
\text { Yilan County (B1) }\end{array}$ & Strong & Oppositional & Success \\
\hline & & $\begin{array}{c}\text { Kuanyin, } \\
\text { Taoyuan County } \\
\text { (B2) }\end{array}$ & Medium & Oppositional & $\begin{array}{l}\text { Success due to } \\
\text { change of location }\end{array}$ \\
\hline & & $\begin{array}{c}\text { Mailiao, } \\
\text { Yunlin County (B3) }\end{array}$ & Weak & Oppositional & Failure \\
\hline (C) Tuntex's naphtha cracker No. 7 & $1994-2000$ & $\begin{array}{l}\text { Chiku, } \\
\text { Tainan County }\end{array}$ & Strong & Divided & Success \\
\hline \multirow{2}{*}{$\begin{array}{l}\text { (D) China Petroleum Corporation's } \\
\text { naphtha cracker No. } 8\end{array}$} & \multirow{2}{*}{ 1999-2002 } & $\begin{array}{l}\text { Fangliao, } \\
\text { Pingtung County } \\
\text { (D1) }\end{array}$ & Weak & Oppositional & Success \\
\hline & & $\begin{array}{c}\text { Putai, } \\
\text { Chiayi County (D2) }\end{array}$ & Weak & $\begin{array}{l}\text { From neutral } \\
\text { to oppositional }\end{array}$ & Success \\
\hline $\begin{array}{l}\text { (E) China Petroleum Corporation's } \\
\text { upgrading of naphtha cracker No. } 3\end{array}$ & $2005-2008$ & $\begin{array}{l}\text { Linyuan, } \\
\text { Kaohsiung County }\end{array}$ & Medium & Supportive & Failure \\
\hline \multirow{2}{*}{ (F) Kuokuang petrochemical project } & \multirow{2}{*}{$2005-2011$} & $\begin{array}{c}\text { Taihsi, } \\
\text { Yunlin County (F1) }\end{array}$ & Weak & Supportive & $\begin{array}{l}\text { Success due to } \\
\text { change of location }\end{array}$ \\
\hline & & $\begin{array}{l}\text { Tacheng, Changhua } \\
\text { County (F2) }\end{array}$ & Strong & $\begin{array}{l}\text { From supportive } \\
\text { to oppositional }\end{array}$ & Success \\
\hline
\end{tabular}

The above table summarises the historical survey of these ten cases.

ganising the Changhua chapter of the Taiwan Environmental Protection Union in 1988, but she subsequently deviated from her environmental stance to promote economic development. Weng's about-face therefore showed that once the appeal of environmental protection became mainstream, it was possible to change the DPP's position.

In early 2011, Su Tseng-chang and Tsai Ing-wen, two heavyweight contenders in the DPP primary for the presidential election, also jumped on the anti-Kuokuang bandwagon. Su and Tsai served as premier and vice-premier respectively when the Kuokuang project was first proposed in 2006. Clearly as the anti-Kuokuang movement gained momentum, DPP politicians found it expedient to follow the trend, even at the risk of appearing inconsistent. With the DPP now in the opposition camp, the ruling KMT faced greater political pressure. Since Ma Ying-jeou was facing his re-election challenge within one year, he decided to abandon the Kuokuang project as a political liability. In an emergency press conference in April 2011, Ma terminated the controversial project and announced his support for wetland conservation.

The Kuokuang project was analogous to the Pinnan Industrial Zone in that large-area reclamation would have resulted in irreversible damage to local ecology and livelihoods. Nevertheless, Changhua activists secured their victory mostly on their own, as the DPP politicians were opportunistic latecomers rather than initiators of the movement. Activists were particularly successful in changing the initially bipartisan support for Kuokuang into bipartisan opposition, thus writing an unprecedented chapter in Taiwan's environmentalism history.

\section{The recipe for successful environmental resistance}

Robert Weller contends that the rise of Taiwan's environmentalism in the mid-1980s was no less than a process of "discovering nature," since a new awareness of pollution revolutionised many people's everyday lives. (27) The

27. Robert Weller, Discovering Nature: Globalization and Environmental Culture in China and Taiwan, Cambridge, Cambridge University Press, 2006 
above survey confirms this observation in that every petrochemical industry projects since then has met with varying degrees of local resistance that lengthened the time between initial planning and execution. Moreover, site selection became increasingly complicated as new projects were often forced to seek alternative locations.

Among the six proposed projects, only three $(A, B 3, E)$ finally went into operation. Two of them $(A, E)$ involved brownfield redevelopment on land already in use. The cases of Houchin and Linyuan indicate that the existence of petrochemical facilities tended to constrain popular mobilisation because some local residents relied on them for livelihood. In addition, good-neighbour compensation universalised in the 1990s brought about closer ties between industrial producers and community elites, which further reduced the likelihood that the latter would champion the rights of pollution victims. Greenfield development appeared to encounter a greater magnitude of resistance, since it involved massive social and ecological change at the localities in question. Petrochemical producers therefore often chose the most backward areas for their development sites, not only because of land prices, but also because less modernisation meant less environmental awareness and weaker resistance. Mailiao (B3), Chiku (C), Putai (D2), Taihsi (F1), and Tacheng (F2) are all impoverished seaside communities. Incidentally, targeting poor greenfield sites in order to neutralise the local opposition to hazardous facilities is also a common practice by Japanese nuclear enegery developers. (28)

Over the years, the political influence of local executives was on the rise and became a critical factor in successful resistance. In the Yilan movement (B1), county magistrate Chen Ting-nan's pro-environment stance helped local mobilisation in defiance of the central government's authoritarian decision. In China Petroleum Corporation's naphtha cracker No. 8 (D1), the Pingtung county magistrate Su Chia-chuan's announcement of his opposition even spared the need for local mobilisation from below. During Su Chihfen's tenure as the Yunlin county magistrate, the local government was no longer receptive to petrochemical industrialisation, which was one of the reasons that Kuokuang decided to abandon its Taihsi plan (F2). The growing influence of local government is also corroborated in a study on transport construction. ${ }^{(29)}$

Alternatively, if local executives were not on the side of environmentalism, stronger mobilisation was a necessary condition for a successful protest. The Chiku case (C) offers a partial confirmation here since it was ultimately the bankruptcy of developers that frustrated the project to develop the Chiku lagoon. The anti-Kuokuang movement in Tacheng (F2) emerged victorious because its activists were able to raise its national profile by securing the support of outsiders. Once the anti-Kuokuang movement gained momentum, politicians had no choice but to jump on the pro-environment bandwagon.

Thus, by discounting the cases in which developers were not entirely satisfied with the proposed sites, such as B2 and D2, there are clearly two conditions for successful resistance: principled opposition from local executives and the strength of popular mobilisation.

\section{From DPP Leadership to Movement Autonomy}

The DPP's pro-environment profile faded significantly, especially during its national incumbency from 2000 to 2008 . ${ }^{(30)}$ Committed environmental activists held a prevailing view that the DPP and KMT differed little in terms of social issues, and that the only meaningful political cleavage was in their attitudes towards China. The above historical review offers a more nuanced modification of this view.

Firstly, to be exact, it was not the experience of national governance that pushed the DPP towards a pro-development orientation; its local executives had been leaning in that direction prior to 2000, as evidenced by Chen Tangshan's support for the Pinnan Industrial Zone. In fact, it seemed that promoting hometown prosperity was such a strong motivation that some local DPP politicians, such as Yang Chiu-hsing and Weng Chin-chu, were willing to abandon their past environmentalism. The gradual rise of this pro-development tendency clearly gained the upper hand over the pro-environment Yilan model, which was more or less imitated in Pingtung, Chiayi, and Yunlin, and thus paved the way for the DPP's drift.

Even with the DPP's new orientation, it is still too early to apply the "end of ideologies" to contemporary Taiwan's political spectrum. Although the environmental movement has become less partisan in recent years, prodevelopment mobilisation has not followed suit, since launching mass campaigns for the petrochemical industry has been a common strategy by KMT politicians. Particularly in Pingtung (D1) and Chiayi (D2), where the DPP was hegemonic, the KMT challengers actually put more emphasis on industrial development in order to highlight their different orientation. Moreover, throughout the ten cases examined here, none of the KMT politicians supported the environmentalists when the opposition initially emerged. The last-minute about-face by Ma Ying-jeou on the Kuokuang project (F2) was largely a political expediency in reaction to the DPP's earlier shift. Hence, eight years out of power did not change the KMT's fundamentally developmentalist outlook, nor was its entrenched relationship with the business community altered. Therefore, ideological rivalry still plays a role in Taiwan's party politics. It is not surprising that environmentalists find it easier to persuade the DPP to support their cause than the KMT.

More importantly, Taiwan's environmental movement weaned itself off its earlier reliance on the DPP leadership because it learned how to obtain trans-local resources. Before the mid-1990s, there were two patterns of protest mobilisation: either movement was restricted to the afflicted community alone, as in Houchin (A) and Kuanyin (B1), or the Taiwan Environmental Protection Union was the only channel for external support, as in Yilan (B1) and Mailiao (B3). Since then, environmentalists have managed to establish broader coalitions to fight petrochemical pollution. The Chiku movement (C) practically became a common concern for all southern environmentalists. An upgrade from the regional to the national level occurred in the anti-Kuokuang movement (F2), which actually succeeded based on nationwide support. One source of enhanced movement autonomy comes from the power of popular epidemiology. In recent years, a number of activist scientists in leading universities have produced solid evidence that existing petrochemical factories have given rise to negative health impacts. In 2010, Tsung Ben-jei (莊秉潔) of National Chung Hsing University modelled the aerodynamic flow of fine particulate matters smaller than $2.5 \mathrm{mi}-$ crometers (PM2.5) if Kuokuang went into production and found that the

28. Simona Alba Grano and Ping-lan Tu, "Development vs. Environment in Taibei," Journal of Current Chinese Affairs, Vol. 41, No. 2, 2012, pp. 121-154.

29. Martin Dusinberre and Daniel P. Aldrich, "Hatoko Comes Home: Civil Society and Nuclear Power in Japan," Journal of Asian Studies, Vol. 70, No. 3, pp. 683-705.

30. Ming-sho Ho, "Weakened State and Social Movement: The Paradox of Taiwanese Environmental Politics after the Power Transfer," Journal of Contemporary China, Vol. 14, 2005, pp. 339-352. FangLong Shih, "Generating Power in Taiwan: Nuclear, Political and Religious Power," Culture and Religion, Vol. 13, No, 3, 2012, pp. 295-313. 
project would shorten the life expectancy of the average citizen by 23 days. Although his calculation was challenged by officials and the Kuokuang management, mass media amplified this message to the broader public and helped the anti-Kuokuang movement. In 2012, Chan Chang-chuan (詹長 權) of National Taiwan University finished a three-year study sponsored by the Yunlin County government that demonstrated a significant increase in the incidence of cancer within ten kilometres of Formosa Plastics Group's naphtha cracker No. 6. In short, the movement capacity of Taiwan's environmentalism demonstrated considerable growth, thereby outweighing the DPP factor in determining movement outcomes.

\section{Conclusion}

The petrochemical industry has an inherent tension with environmental protection. Its insatiable hunger for land, water, and energy and its emission of toxic wastewater and greenhouse gases has placed a heavy environmental burden on resource-poor and population-dense Taiwan. The petrochemical industry underpinned rapid post-war economic growth while its environmental costs were ignored by the authoritarian government. As soon as political control was gradually relaxed, further expansion of the petrochemical industry inevitably incurred grassroots opposition, thus giving rise to a strong current in Taiwan's environmental movement.
This article looked at ten cases of naphtha cracker construction from 1987 to 2011 in order to understand the trajectory of Taiwan's environmental politics. It is clear that petrochemical development became controversial and contentious once people gained their political rights of speech, organisation, and protest. Over the long haul, civil society gained strength and politicians' leadership of the movement waned. The DPP's pro-development turn has significantly narrowed the political contrast between the two major parties on environmental protection; however, ideological difference remain, as the KMT remains committed to further petrochemical expansion.

My observation ends with the environmentalists' victory in the Kuokuang case in 2011, which was unique in many ways. For the first time, environmentalists were eventually able to gain bipartisan support. It was all the more remarkable because they had to mobilise without the leadership of politicians. It remains to be seen whether the Kuokuang success can establish a national consensus and thus terminate the protracted warfare between environmentalists and the petrochemical industry.

Ming-sho Ho is a professor at the Department of Sociology, National Taiwan University.

Department of Sociology, National Taiwan University, No. 1, Roosevelt Rd. Sec 4., Taipei City, 10617, Taiwan

(mingshoho@gmail.com). 